\title{
Efektifitas Penyelenggaraan Otonomi Daerah Berbasis Elektronik Terhadap Upaya Pencegahan Tindak Pidana Korupsi (Studi Kasus Pemerintah Daerah Kota Dan Kabupaten Bekasi)
}

\author{
Rahmat Saputra $^{1}$, Apriyanti Widiansyah ${ }^{2}$ \\ ${ }^{1}$ Universitas Bhayangkara Jakarta Raya \\ e-mail : rahmat.saputra@dsn.ubharajaya.ac.id \\ ${ }^{2}$ Universitas Bhayangkara Jakarta Raya \\ e-mail: apriyanti.widiansyah@dsn.ubharajaya.ac.id
}

\begin{abstract}
Cara Sitasi: Rahmat S, Apriyanti W, (2021) Efektifitas Penyelenggaraan Otonomi Daerah Berbasis Elektronik Terhadap Upaya Pencegahan Tindak Pidana Korupsi (Studi Kasus Pemerintah Daerah Kota Dan Kabupaten Bekasi), 2021 21(1), 39-50 Retrieved from https://doi.org/10.31294/jc.v19i2
\end{abstract}

\begin{abstract}
One of the government's breakthroughs in facing the era of the industrial revolution 4.0 towards the implementation of electronic-based regional autonomy is Presidential Regulation No. 95 of 2018 concerning Electronic-Based Government Systems. Technological developments will create (to create), access (to access), manage (to process), and utilize (to utilize) information precisely and accurately. Information is a very valuable commodity in the era of globalization to be mastered in order to increase the competitiveness of an organization in a sustainable manner. This phenomenon is important to study, because this system is expected to be a solution related to the implementation of effective, efficient, transparent and accountable local governments for efforts to prevent corruption by utilizing the application of this technology.

This type of legal research used by researchers is empirical sociological legal research. Empirical sociological legal research that includes research on legal identification (unwritten) and research on legal effectiveness. Data collection was carried out by interview, observation and literature study. This study aims to analyze the effectiveness of the implementation of electronic-based regional autonomy on efforts to prevent corruption (a case study of the Bekasi City and Regency Government). The conclusion is that the effectiveness of the implementation of electronic-based autonomy is not optimal, there are still problems that there is no national integrated SPBE governance, SPBE has not been applied to the implementation of government administration and public services as a whole and optimally, the reach of ICT infrastructure to all regions and to all levels of society not optimal, the limited number of ASN employees who have ICT technical competence. based on the substance of the regulations, it is necessary to regulate the authority of the central government and local governments in managing e-government. Meanwhile, the culture of sharing data and information between government agencies is still low; Information and communication technology (ICT) infrastructure has not reached all agencies, and information security management is weak in almost all government agencies. Based on the application of an electronic-based government system towards the prevention of corruption, one of which is to combat corruption is preventive efforts in addition to repressive measures.
\end{abstract}

Keywords: Effectiveness; Electronic-Based Regional Autonomy; Prevention of Corruption Crime

\section{PENDAHULUAN}

Kemunculan internet telah membawa perubahan bagi perkembangan ilmu pengetahuan dan teknologi. Internet mampu membawa manusia kepada tingkat kualitas kehidupan yang lebih baik, disisi lain internet juga berpotensi menimbulkan permasalahan yang besar sebagai akibat dari penyalahgunaan internet tersebut. Konsep baru kemunculan internet pada bidang perdagangan ( $e$ commerce), bidang pendidikan (e-learning), bidang pemerintahan ( $e$ - government), bidang bisnis ( $e$ business) dan bidang politik (e-democracy). Menyikapi kemunculan internet tersebut harus didukung instrumen hukum sebagai penopang pemanfaatan yang tepat, maka diperlukan konsep perencanaan pembangunan hukum di bidang teknologi informasi dan komunikasi baik dari segi substansi hukum, struktur hukum, budaya hukum dan penegakan hukumnya. Beberapa bidang menuju smart city adalah bidang pengadaan barang dan jasa, kebijakan infrastruktur, e-perjanjian, sistem kinerja daerah (e-musrembang, e-planning, e-budgeting, $e$ money, e-skip), layanan publik menuju smart city dan ketersediaan sumber daya manusia.

Salah satu trobosan pemerintah dalam menghadapi era revolusi 1ndustry 4.0 terhadap 
penyelenggaraan otonomi daerah berbasis elektronik adalah Peraturan Presiden No. 95 Tahun 2018 tentang Sistem Pemerintahan Berbasis Elektronik. Perkembangan Teknologi akan menciptakan (to create), mengakses (to access), mengelola ( to prosess), dan memanfaatkan (to utilize) informasi secara tepat dan akurat. Informasi merupakan komoditi yang sangat berharga di era globalisasi untuk dikuasai dalam rangka meningkatkan daya saing suatu organisasi secara berkelanjutan.(Zainal A Hasibuan, 2007)

Berdasarkan data dari Komisi Pemberantasan Korupsi (KPK) jumlah kepala daerah yang terjerat melakukan korupsi sebanyak 104 orang (Lia Hutasoit, 2018) salah satu Kepala Daerah yang tersandung korupsi adalah Bupati Bekasi Neneng Hasanah Yasin oleh Komisi Pemberantasan Korupsi menjadikan bupati perempuan itu sebagai kepala daerah yang ke-99 terjerat korupsi. Sistem Pemerintah Berbasis Elektonik sebagaimana diatur didalam Peraturan Presiden No. 95 Tahun 2018 diharapkan bisa menjadi solusi terkait penyelenggaraan pemerintah daerah yang efektif, efisien, transparansi dan akuntabel terhadap upaya pencegahan tindak pidana korupsi dengan memanfaatkan penerapan teknologi tersebut. Penerapan sistem pemerintah berbasis elektonik diharapkan dapat memberikan kontribusi yang signifikan penyelenggaraan pemerintah di daerah. Berdasarkan uraian latar belakang di atas, peneliti melihat bahwa efektifitas penyelenggaraan otonomi daerah berbasis elektronik menjadi sangat penting untuk dikaji.

Penelitian ini akan menitikberatkan fokus penelitian Bagaimana Efektifitas Penyelenggaraan Otonomi Daerah Berbasis Elektronik Terhadap Upaya Pencegahan Tindak Pidana Korupsi (Studi Kasus Pemerintah Daerah Kota dan Kabupaten Bekasi). Lebih lanjut, penelitian ini memiliki tujuan dengan sistem ini diharapkan bisa menjadi solusi terkait penyelenggaraan pemerintah daerah yang efektif, efisien, transparansi dan akuntabel terhadap upaya pencegahan tindak pidana korupsi dengan memanfaatkan penerapan teknologi tersebut.

Dalam negara kesatuan, tanggungjawab pelaksanaan tugas-tugas pemerintahan pada dasarnya tetap berada di tangan pemerintah pusat. Akan tetapi, sistem pemerintahan Indonesia yang salah satunya menganut asas negara kesatuan yang didesentralisasikan, menyebabkan ada tugas-tugas tertentu yang di urus sendiri, sehingga menimbulkan hubungan timbal balik yang melahikan adanya hubungan kewenangan dan pengawasan. (Ni'matul Huda, 2005)

Berdasarkan Pasal 18 ayat (1) UUD 1945 yang menyatakan "Negara Kesatuan Republik Indonesia dibagi atas daerah-daerah Provinsi dan daerah provinsi itu dibagi atas kabupaten dan kota, yang tiap-tiap provinsi, kabupaten, dan kota itu mempunyai pemerintahan daerah, yang diatur dengan undang-undang”. Otonomi daerah merupakan salah satu agenda utama reformasi yang bertujuan memangkas kesenjangan ekonomi-politik antara pemerintah pusat dan daerah. Seperti kita tahu, kebijakan sentralistis yang dipraktikkan di era Suharto telah memunculkan ketimpangan kewenangan antara pusat dan daerah yang berujung pada munculnya ancaman disintegrasi.

Reformasi 1998 menjadi titik tolak bergesernya paradigma pemerintahan dari sentralistis menuju desentralistis. Publik pun menaruh harapan besar bahwa desentralisasi yang dimanifestasikan ke dalam aturan otonomi daerah akan membawa perbaikan bagi daerah. Publik berharap, otonomi daerah akan membawa mewujudkan pemerintahan daerah yang demokratis, adaptif pada lokalitas, namun tetap dalam kerangka integritas-nasional. Namun, dalam perkembangan selanjutnya, harapan itu justru kian jauh panggang dari api. Dua dasawarsa sejak era reformasi bergulir, otonomi daerah justru berjalan di luar rel yang seharusnya. Harapan akan pemerintahan yang demokratis dan bersih, justru ditelikung oleh kenyataan maraknya korupsi di level daerah.

Bentuk upaya pemberantasan korupsi oleh KPK dengan operasi tangkap tangan sebagai salah satu strategi andalan KPK tentu layak dipertahankan. Namun demikian, kita harus sadar bahwa pemberantasan korupsi tentu tidak akan tuntas jika hanya dibebankan pada KPK dengan model operasi tangkap tangan. Diperlukan upaya pencegahan korupsi yang lebih sistematis dan terencana untuk menutup celah potensi korupsi yang disisakan oleh sistem otonomi daerah tersebut. Salah satu yang mendesak untuk segera dilakukan ialah memastikan semua aktivitas penyusunan anggaran dan pengadaan barang dilakukan secara akuntabel dan transparan. Mekanisme layanan e-procurement, e-catalog, eplanning dan $e$-budgetting idealnya menjadi hal yang wajib dipraktikkan oleh semua daerah di Indonesia.

Menurut Indrajit (Richardus Eko Indrajit, 2002) E-government merupakan suatu mekanisme interaksi baru antara pemerintah dengan masyarakat dan kalangan lain yang berkepentingan, dengan melibatkan penggunaan teknologi informasi (terutama internet) dengan tujuan memperbaiki mutu (kualitas) pelayanan E-Government adalah penyelenggaraan kepemerintahan berbasiskan elektronik untuk meningkatkan kualitas layanan publik secara efisien, efektif dan interaktif.

Menurut Budi Rianto (Rianto Budi, 2012) menyimpulkan bahwa E- Government merupakan bentuk aplikasi pelaksanaan tugas dan tatalaksana pemerintahan menggunakan teknologi telematika atau teknologi informasi dan komunikasi. Aplikasi E-Government memberikan peluang meningkatkan dan mengoptimalkan hubungan antar instansi pemerintah, hubungan antara pemerintah dengan dunia usaha dan masyarakat. Mekanisme hubungan 
itu melalui pemanfaatan teknologi informasi yang merupakan kolaborasi atau penggabungan antara komputer dan sistem jaringan komunikasi.

Perkembangan penerapan e-government di Indonesia dapat diamati dengan melakukan tinjauan pustaka yang menunjukkan adanya perkembangan penerapan sistem pemerintahan berbasis elektronik di Indonesia. Sejumlah hasil kajian tentang penerapan $e$ - government sudah menjadi bahan kajian penggiat hukum di Indonesia, akan tetapi penulis menjamin belum pernah ada penelitian Efektifitas Penyelenggaraan Otonomi Daerah Berbasis Elektornik Terhadap Upaya Pencegahan Tindak Pidana Korupsi, walaupu begitu, peneliti perlu meninjau untuk melihat kemiripan dengan penelitian yang ada sebelumnya terkait dengan tema ini. Oleh karena luaran yang ditargetkan peneliti adalah jurnal hukum nasional yang terakreditasi, maka penulis hanya memperbandingkan dengan jurnal nasional yang terakreditasi saja, yakni :

\begin{tabular}{|c|c|c|}
\hline Nama & Jenis Publikasi & Perbedaan \\
\hline $\begin{array}{l}\text { Iqbal Aidar } \\
\text { Idrus, } \\
\text { Ummi } \\
\text { Zakiyah, } \\
\text { Lisa Hodiyah } \\
\text { (Iqbal Aidar } \\
\text { Idrus, Ummi } \\
\text { Zakiyah, } \\
\text { 2017) }\end{array}$ & 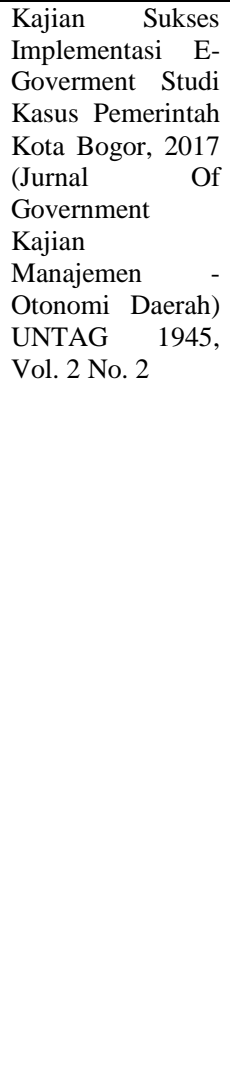 & 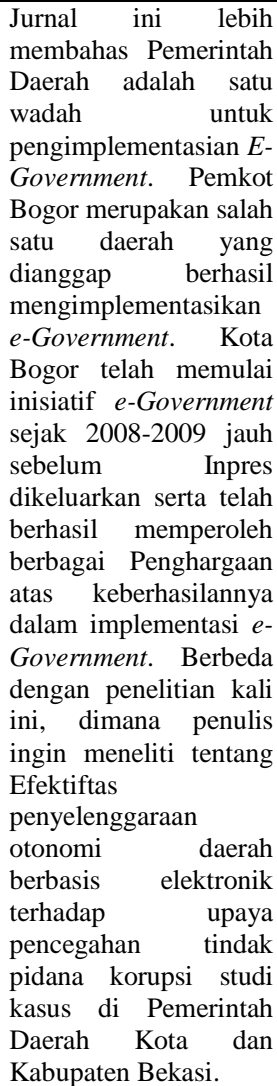 \\
\hline $\begin{array}{l}\text { Dien Novita } \\
\text { (Dien Novita, } \\
2014 \text { ) }\end{array}$ & $\begin{array}{l}\text { Faktor-faktor } \\
\text { penghambat } \\
\text { pengembangan e- } \\
\text { government } \\
\text { dengan Studi } \\
\text { Kasus Pemerintah } \\
\text { Kota Palembang, } \\
\text { Sumatera Selatan } \\
\text { Jurnal Eksplora } \\
\text { Informatika, 2014, } \\
\text { Vol. } 4 \text { No. } 1\end{array}$ & $\begin{array}{lr}\begin{array}{l}\text { Jurnal ini } \\
\text { membahas }\end{array} & \begin{array}{r}\text { lebih } \\
\text { faktor }\end{array} \\
\text { hambatan yang } & \text { paling } \\
\text { sebagai } & \text { dalam } \\
\text { pengembangan } & e- \\
\text { government } & \text { seperti } \\
\text { lemahnya } & \\
\text { kepemimpinan, } \\
\text { langkanya } & \text { SDM, } \\
\text { kesenjangan } & \text { digital, } \\
\text { kurangnya koordinasi } \\
\text { dan } & \text { lemahnya } \\
\text { peraturan/kebijakan. }\end{array}$ \\
\hline
\end{tabular}

\begin{tabular}{|c|c|c|}
\hline & & $\begin{array}{l}\text { Berbeda dengan } \\
\text { peneliti kali ini, dimana } \\
\text { penulis ingin meneliti } \\
\text { efektifitas } \\
\text { penyelenggaraan } \\
\text { otonomi daerah } \\
\text { berbasis elektronik } \\
\text { faktor yang } \\
\text { menyebabkan kurang } \\
\text { efektifnya } \\
\text { penyelenggaraan } \\
\text { sistem pemerintah } \\
\text { berbasis elektronik. }\end{array}$ \\
\hline $\begin{array}{l}\text { Loura } \\
\text { Hardjaloka } \\
\text { (Loura } \\
\text { Hardjaloka, } \\
\text { 2015) }\end{array}$ & $\begin{array}{lr}\text { Penerapan } & e- \\
\text { government } & \mathrm{di} \\
\text { Indonesia } & \mathrm{dan} \\
\text { negara } & \text { lainnya } \\
\text { sebagai } & \text { solusi } \\
\text { pemberantarasan } \\
\text { korupsi di } & \text { sector } \\
\text { publik, Jurnal } \\
\text { Rechts Vinding, } \\
\text { Vol. 3 No.3(2015) }\end{array}$ & $\begin{array}{lr}\text { Jurnal ini } & \text { lebih } \\
\text { membahas Penerapan } & \text { e-government } \\
\text { Indonesia } & \text { telah } \\
\text { dilakukan } & \text { untuk } \\
\text { meningkatkan } & \text { prinsip- } \\
\text { prinsip } & \text { good } \\
\text { governance dalam } \\
\text { rangka pemberantasan } \\
\text { korupsi, antara lain } \\
\text { pengadaan barang dan } \\
\text { jasa, perpajakan, dan } \\
\text { perjinan. Berbeda } \\
\text { dengan peneliti kali ini, } \\
\text { dimana penulis ingin } \\
\text { meneliti efektifitas } \\
\text { penyelenggaraan } \\
\text { otonomi daerah } \\
\text { berbasis elektronik } \\
\text { terkait dengan masih } \\
\text { banyaknya kepala } \\
\text { daerah yang terkena } \\
\text { tindak pidana korupsi. }\end{array}$ \\
\hline
\end{tabular}

Berdasarkan penelusuran kepustakaan tersebut di atas, peneliti melihat bahwa efektifitas penyelenggaraan otonomi daerah berbasis elektronik terhadap upaya pencegahan korupsi belum dikaji sepenuhnya. Atas dasar itu, peneliti melihat urgensi yang sangat penting untuk menjadi bahan dan objek kajian penelitian selanjutnya dengan merujuk kepada data-data sebagaimana dituangkan dalam penelitian terdahulu.

\section{METODOLOGI PENELITIAN}

Jenis penelitian hukum yang digunakan oleh peneliti yaitu penelitian hukum empiris. Menurut Soejono Soekanto. (Mukti fajar dan Yulianto Achmad, 2013) penelitian hukum sosiologis empiris yang mencakup, penelitian terhadap identifikasi hukum (tidak tertulis) dan penelitian terhadap efektifitas hukum. Penelitian hukum sosiologis atau empiris hendak mengadakan pengukuran terhadap peraturan perundang-undangan tertentu mengenai efektivitasnya, maka definisi-definisi operasionil dapat diambil dari peraturan perundang-undangan tersebut. Menurut Ronny Hanitijo Soemitro, bahwa penelitian hukum empiris atau sosiologis yaitu penelitian hukum yang memperoleh datanya dari data primer atau data yang diperoleh langsung dari masyarakat. (Ronny Hanitijo Soemitro Dalam bukunya Mukti Fajar dan Yulianto Achmad, 2010) 
Sumber data dalam penelitian ini menggunakan data empiris bebas. Yaitu dalam materi penelitian ini menggunakan jenis data Primer (Field Research) dan Sekuder (Library Research). Data primer, yaitu data yang diperoleh terutama dari hasil penelitian empiris, yaitu penelitian yang dilakukan dalam masyarakat berdasarkan observasi/pengamatan dan wawancara secara langsung. Data sekunder adalah sumber data yang akan diperoleh melalui kajian pustaka karya ilmiah, hasil penelitian atau teori-teori para ahli yang berhubungan dengan masalah yang akan dibahas. Data tersier adalah ensiklopedia, bahan dari internet, bibiliografi dan sebagainya primer. Adapun lokasi penelitian yang penulis pilih ialah pada Pemerintahan Daerah Kota dan Kabupaten Bekasi.

Dalam penelitian ini, peneliti mengambil populasi diantaranya pegawai Pemerintah Daerah Kota dan Kabupaten Bekasi dan masyarakat umum khususnya masyarakat pengguna pelayanan berbasis elektronik yang berada di Pemda Kota dan Kabupaten Bekasi. Dalam penelitian ini peneliti menggunakan teknik dalam pengambilan sampel secara acak sederhana (Teknik Sampling). Adapun yang menjadi sampel dalam penelitian ini yaitu 20 orang dari pegawai Pemda Kota dan Kabupaten Bekasi dan 20 orang dari masyarakat umum khususnya bagi para pengguna layanan berbasis elektronik di Pemerintahan Daerah Kota dan Kabupaten Bekasi. Adapun analisis data yang digunakan oleh peneliti dalam penelitian hukum menggunakan sifat analisis yang Deskriptif adalah, bahwa peneliti dalam menganalisis berkeinginan untuk memberikan gambaran atau pemaparan atas subjek dan objek penelitian sebagaimana hasil penelitian yang dilakukannya serta menggunakan pendekatan kualitatif adalah suatu cara analisis hasil penelitian yang menghasilkan data deskriptif analitis, yaitu data yang dinyatakan oleh responden sacara tertulis atau lisan serta juga tingkah laku yang nyata, yang diteliti dan dipelajari sebagai sesuatu yang utuh.(Mukti fajar dan Yulianto Achmad, 2013)

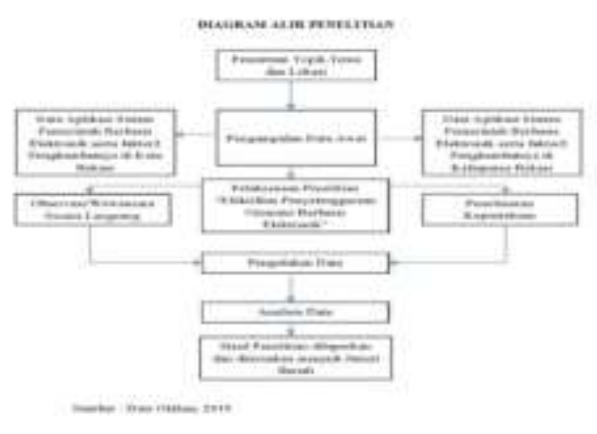

\section{HASIL DAN PEMBAHASAN}

Penelitian ini dilakukan agar mengetahui bagaimana efektifitas penyelenggaraan otonomi daerah berbasis elektronik terhadap upaya pencegahan tindak pidana korupsi (studi kasus Pemerintah Daerah Kota dan Kabupaten Bekasi) . Berdasarkan hasil temuan dilapangan ini peneliti menemukan bahwa manajemen Electronic Government di Pemkot Bekasi dan Pemda Kabupaten Bekasi mengedepankan prinsip good governance didukung kelembagaan yang efektif dan kinerja aparatur yang kompeten, serta pemanfaatan teknologi informasi. Penerapan E-Government di lingkungan pemerintahan dilakukan dalam rangka pemanfaatan teknologi informasi yang akan membawa dampak pada perubahan pola pikir dan cara pandang masyarakat dalam melakukan berbagai kegiatan yang berorientasi pada aspek kemudahan dan kecepatan dalam pertukaran akses informasi.

Penerapan E-Government juga sering dikatakan sebagai salah satu upaya reformasi birokrasi menuju terwujudnya good governance. Analisis manajemen Electronic Government dilihat dengan menggunakan empat fungsi manajemen, yakni perencanaan (planning), pengorganisasian (organizing), penggerakan (actuating), dan pengawasan (controlling). Pemkot Bekasi dan Pemda Kabupaten Bekasi merupakan salah satu kota dan kabupaten yang menerapkan E-Government di dalam kegiatan pemerintahannya, hal ini juga termuat di dalam misi penyelenggaraan Pemerintah Daerah Kota Bekasi dan Kabupaten Bekasi, yaitu misi pertama: meningkatkan sarana dan prasarana teknologi informasi, kedua mewujudkan tata kelola kepemerintahan yang baik melalui penerapan $E$ Government, melaksanakan pelayanan informasi dan komunikasi kepada masyarakat serta promosi potensi. Penerapan E-Government di lingkungan Pemerintah Daerah Kota Bekasi dan Kabupaten Bekasi dalam upaya peningkatan pelayanan dan kebebasan akses informasi bagi masyarakat.

Faktor pendorong dan penghambat penerapan E-Government di Pemerintah Daerah Kota Bekasi dan Kabupaten Bekasi dapat dilihat melalui elemen sukses pengembangan E-Government, dimana di dalam menerapkan konsep digitalisasi pada sektor publik harus memperhatikan elemen sukses tersebut karena dapat mendorong keberhasilan $E$ Government, tetapi juga dapat menjadi faktor penghambat penerapan E-Government. Adapun elemen-elemen sukses pengembangan $E$ Government tersebut meliputi Support, Capacity, dan Value.

Penyelenggaraan pemerintahan daerah dalam mengelola pemberian layanan dengan dukungan teknologi infomasi. Kebutuhan tersebut didapat dengan mudahnya diakses berbagai layanan secara online yang begitu cepat, mudah, dan murah. Egovernment ini lahir karena tuntutan zaman, perubahan dan untuk mengefektifkan pelayanan yang 
sebelumnya lambat, agar bisa menjadi lebih efektif dan efesien. Hal tersebut juga memiliki dampak pada pengelolaan pembangunan khususnya perkotaan guna menjamin pengembangan kapasitas pemerintah Daerah.

Smart city mengupayakan pemberian layanan lebih inovatif kepada masyarakat. Smart city requires a variety of innovative services that provide information to all citizens about all aspects of city life via interactive and internet-based applications. Penguasaan teknologi informasi menjadi aspek baru dalam pengembangan kapasitas pemerintahan daerah.

Perkembangan E-Government dalam perkembangan smart city di Indonesia menemui tantangan. Hal tersebut datang dari regulasi dan juga kapasitas pemerintah daerah (Institusional \& infrastruktur IT). Kendala infrastruktur koneksi jaringan dan sosialisasi kepada masyarakat disebabkan minimnya masyarakat mengakses teknologi dan internet. Selain infrastruktur IT dan juga kebijakan yang mendukung keberlangsungan. The smart city development in Indonesia is growing fast although there is no clear legal foundation for smart city in Indonesia. Selain itu, Hasil evaluasi tentang penerapan E-Government menunjukkan hasil yang sangat mengejutkan implementasi $E$ Government di Indonesia banyak yang mengalami ketidak suksesan, karena adanya kurangnya pemahaman paradigma tentang E-Government yang tidak sesuai dengan konsep yang benar.

Pengelolaan layanan berbasis aplikasi memerlukan kehadalan sumberdaya baik itu apartur yang berkerja serta dukungan pembiayaan. Pada segi sumberdaya aparatur yang dimiliki juga terbagi dua yaitu aparatur yang menyiapkan dan mengembangakan aplikasi layanan serta aparatur yang mengelola layanan. Untuk aparatur pengembangan dan penyiapan dikelola secara bersama diskominfo yang menjadi leading sektornya. Pada prakterknya aparatur pengelola aplikasi tentu menjadi ujung tombak dalam menjaga pelayanan yang diberikan, sehingga dapat berjalan lancar. Memang sangat sedikit ditemukan kendala yang dihadapi oleh pengelola aplikasi layanan. Minimnya permasalahan pengelolaan aplikasi mengindikasikan kuatnya pemahanan aparatur pengelola dalam mengunakan aplikasi layanan ada.

Pemanfaatan pembiayaan juga menjadi ujung tombak guna mendorong pemberian layanan dengan E- government dalam penyediaan aplikasi layanan dan perangkat lainnya. Komitmen kepala daerah dan juga transfomrasi pengelolaan e-government dengan panduan masterplan smart city menjadi pendorong penyelenggaraan terhadap dukungan pembiayaan. Pembiayaan yang dirasakan masih tereduksi secara bertahap, reduksi tersebut karena ada pertukaran dengan peningkatan kapasitas aparatur yang mampu memahami pengembangan dan pembuatan aplikasi secara baik dan tepat. Pembiayaan diinvestasikan pada pengembangan sumberdaya manusia ketimbang untuk pembiayaan penyediaan aplikasi pada pihak ketiga. Lebih dari itu, SDM pengelola dan pengembang aplikasi beserta diskominfo sudah menjadi bast practices bagi daerah lainnya dalam mengelola E-government berbasis web. Secara tidak langsung menghadirkan daerah lain dalam berbagi pengetahuan untuk pengembangan aplikasil layanan.

\section{Efektifitas Penyelenggaraan Otonomi Daerah Berbasis Elektronik.}

Upaya pemerintah mewujudkan visi misi dalam pemerintahannya, dengan menyusun berbagai program guna mencapai tujuan tertentu dan kemudian program tersebut diimplementasikan melalui berbagai kebijakan. Terdapat tiga unsur dalam implementasi program yaitu implementor sebagai unsur pelaksana; program yang akan dijalankan; dan target grup sebagai kelompok sasaran. (Maryuni, 2015) Implementasi program dilaksanakan dengan melalui tahapan perencanaan (planing), pelaksanaan, pengawasan, dan evaluasi. (Medan Yonathan Mael, 2017) Unsur dan tahapan dimaksud jika dijalankan menjadi sebuah upaya agar program terlaksana dengan baik. Salah satu program pemerintah yang trend di Indonesia adalah program "Smart City/Kota Cerdas". Program Smart City sebagai upaya menyelesaikan berbagai permasalahan kota, dengan menggunakan teknologi komunikasi sebagai salah satu tools. Program Smart City menyasar bidang layanan publik, layanan transportasi, pendidikan, lingkungan hingga layanan kesehatan, dengan tujuan memberikan kemudahan dan kemanfaatan demi tercapainya masyarakat yang berkualitas.(Meijer, A., \& Bolívar, 2016)

Pemerintah kota Bekasi juga memiliki program Smart City. Program yang diberi nama Bekasi Smart City dirintis dan diinisiasi oleh Walikota sebagai bagian dari gerakan program dalam visi Bekasi Cerdas. Smart City disusun sebagai program yang membantu mengelola sumber daya manusia dengan tujuan meningkatkan kualitas hidup masyarakat Bekasi, mendukung visi yang telah ditetapkan, yakni menjadi kota humanis, beradab, teratur, maju serta berwawasan lingkungan. Untuk mencapai tujuan Program Smart City, pemerintah kota Bekasi membutuhkan upaya dalam implementasi termasuk upaya komunikasi yang dilakukan. Pentingnya komunikasi bagi pemerintah, agar program dapat dipahami, dan diimplementasikan dengan baik oleh berbagai unsur pelaksana dan target sasaran sehingga tujuan program berhasil. Bekasi sebagai kota yang menerima penghargaan dengan kategori kota tersiap dalam implementasi Smart City di ajang Indonesia Smart Nation Award (ISNA) ke tiga tahun tahun 2018.(Firdaus, 2018)

Hingga saat ini implementasi program Smart City di Kota Bekasi masih terus dilakukan, diantaranya dengan menghadirkan berbagai aplikasi seperti Aplikasi Sorot, Aplikasi Absensi, Aplikasi 
Sikerja, Aplikasi SILAT, POT, Aplikasi Bekasi Iconic, dan Aplikasi RapoRT RW dan SIAP yang terintegrasi dengan Command Center. Namun nampaknya program tersebut belum berhasil terealisasi dengan baik. Aplikasi Smart yang disediakan belum sepenuhnya diberdayagunakan. Buktinya, sebagian aplikasi pelayanan publik hingga kini belum di gunakan atau aplikasi sudah diterapkan namun masyarakat masih menggunakan cara-cara manual. (Yud, 2019)

Keberhasilan sebuah program agar diterapkan dan digunakan oleh masyarakat, selain membutuhkan perencanaan dan tujuan, juga membutuhkan cara yang pas sehingga program itu bisa tepat mencapai sasaran dan tujuan program itu berhasil. Program Smart City Lounge Jakarta, mengkomunikasikan program melalui berbagai upaya sosialisasi, begitu juga dengan program Hay U perizinan Kota Bandung, di sosialisasikan melalui berbagai pendekatan komunikasi, sehingga bukan saja diketahui tetapi juga diterapkan penggunaannya. Berkaca dari kondisi tersebut, artinya komunikasi menjadi penting dalam mengimplementasikan program kepada masyarakat. Komunikasi merupakan wujud dari strategi komunikasi, dimana institusi pemerintah sebagai aktor komunikasi dalam sebuah program. (Sandhu, 2009)

Bila dibandingkan dengan Pemerintah Daerah Kabupaten Bekasi, Pemerintah Kabupaten Bekasi juga sedang melakukan pengembangan $e$ government dengan sasaran dan strategi pengembangan yang jelas. Adapun sasaran yang terkait dengan pengamanan informasi yang ingin dicapai adalah perumusan kebijakan tentang pengamanan informasi serta pembakuan sistem otentikasi dan public key infrastructure untuk menjamin keamanan informasi dalam penyelenggaraan transaksi dengan pihak-pihak lain, terutama yang berkaitan dengan dengan kerahasiaan informasi dan transaksi finansial. Seiring dengan berjalannya waktu, berbagai kegiatan terkait implementasi keamanan informasi telah diselenggarakan oleh Pemerintah Kabupaten Bekasi. Pada tahun 2014, Pemerintah Kabupaten Bekasi telah melakukan evaluasi tingkat kematangan Indeks KAMI yang diselenggarakan oleh Direktorat Keamanan Informasi Kementerian Komunikasi dan Informatika. Salah satu kategori yang ada dalam penilaian Indeks KAMI adalah tingkat ketergantungan terhadap peran TIK. Hasil evaluasi pada kategori tingkat ketergantungan terhadap peran TIK adalah tinggi. Secara keseluruhan nilai status kesiapannya adalah 85 dari nilai maksimum 588, hal ini menunjukkan bahwa saat ini TIK merupakan bagian yang tidak terpisahkan dari proses kerja yang berjalan, tetapi kontrol pengamanan yang diterapkan masih belum memadai dan membutuhkan peningkatan di berbagai aspek sesuai dengan kebutuhan kontrol yang seharusnya diterapkan untuk peran TIK dengan tingkat ketergantungan yang tinggi.

Berdasarkan uraian tersebut pengembangan $e$ government pemerintah kota dan kabupaten Bekasi dalam pelaksanaannya belum efektif. Efektivitas diartikan sebagai sesuatu atau keadaan yang mana telah sesuai dengan tujuan atau target yang akan ditempuh atau diharapkan oleh negara. Ada pula yang menyatakan suatu hukum itu dikatakan efektif apabila warga masyarakat berperilaku sesuai yang diharapkan atau dikehendaki oleh hukum. (Soerjono Soekanto, 1985) Sementara itu Hans Kelsen merumuskan tentang efektivitas hukum yang tidak bisa di lepaskan dari validitas hukum, menurut kelsen jika mengemukkan tentang efektifitas hukum sudah barang tentu mesti dikemukakan juga tentang validitas hukum. Validitas hukum menegaskan bahwasanya norma-norma hukum itu saling mengikat mengikat, bahwa orang harus berbuat sesuai dengan yang diharuskan oleh norma-norma hukum, bahwa orang harus mematuhi dan menerapkan norma-norma hukum. Efektifitas hukum berarti bahwa orang benarbenar berbuat sesuai dengan kaidah-kaidah hukum yang berlaku sebagaimana mereka harus berbuat, bahwa norma- norma itu benar-benar diterapkan dan dipatuhi.

Secara konsepsional, maka inti dari efektivitas hukum terletak pada bagian menyerasikan hubungan kaidah-kaidah yang terjabarkan dalam suatu kaidahkaidah yang tetap dan suatu sikap tindak sebagai rangkaian penjabaran nilai tahap akhir, untuk menciptakan, kemudian, dan mempertahankan bagaimana menjaga kebahagian dalam suatu kehidupan. Berdasarkan pemaparan tersebut dapat disimpulkan, bahwa masalah yang utama dari efektivitas hukum sebenarnya terletak dari indikator yang memungkinkan dapat dikatakan efektif atau tidak. Indikatornya mempunyai arti netral. Sehingga dapat muncul sisi positif atau negatif yang terletak pada isi indikator. Kaitannya dalam membahas efektivitas penyelenggaraan otonomi daerah berbasis elektronik terhadap upaya pencegahan tidak pidana korupsi erat kaitannya dengan konsep Lawrence Meir Friedman. tentang tiga unsur sistem hukum (three elements of legal system). Ketiga unsur sistem hukum tersebut adalah sebagai berikut: (Achmad Ali, 2001)

1. Stuktur;

2. Substansi;

3. Kultur hukum.

Teori yang digunakan peneliti untuk memudahkan peneliti dalam menjawab permasalahan hukum yang akan diteliti adalah teori efektifitas hukum. Teori ini menjelaskan bahwa penyelenggara negara merupakan kekuasaan untuk menegakkan norma-norma dan kaidah-kaidah hukum sekaligus nilai-nilai yang ada di belakangnya. Konsep Lawrence Meir Friedman, Ketiga unsur sistem hukum tersebut adalah: 


\section{Stuktur (Structure)}

Kebijakan pengembangan SPBE diinisiasi oleh pemerintah dengan dikeluarkannya Instruksi Presiden Nomor 3 Tahun 2003 tentang Kebijakan dan Strategi Nasional Pengembangan E Government. Implementasi penerapan SPBE telah dihasilkan oleh Instansi Pusat dan Pemerintah Daerah dan memberi kontribusi efisiensi dan efektivitas penyelenggaraan pemerintahan. Namun demikian, hasil pengembangan SPBE dan tingkat maturitasnya masih sangat beragam antar Instansi Pusat dan Pemerintah Daerah. Penerapan Sistem Pemerintahan Berbasis Elektronik (SBPE) yang dilakukan oleh pemerintah Indonesia menunjukkan peningkatan. Hasil survei $e$ Government Development Index (EGDI) yang diselenggarakan oleh United Nations menunjukkan bahwa Indonesia berada di rangking 88 dari 193 negara di tahun 2020. (Dirjen Aptika Kemkominfo, 2019)

Permasalahan pertama adalah belum adanya Tata Kelola SPBE yang terpadu secara nasional. Hal ini ditunjukkan dengan hasil kajian Dewan TIK Nasional tahun 2019 terkait belanja TIK yang tidak efisien secara nasional. Ditemukan bahwa $65 \%$ dari belanja perangkat lunak (aplikasi) termasuk lisensi perangkat lunak digunakan untuk membangun aplikasi yang sejenis antar instansi pemerintah. Permasalahan kedua adalah SPBE belum diterapkan pada penyelenggaraan administrasi pemerintahan dan pelayanan publik secara menyeluruh dan optimal. Penerapan SPBE seharusnya memiliki pengaruh yang kuat terhadap peningkatan kinerja penyelenggaraan pemerintahan. Namun demikian, masih terdapat permasalahan kinerja pada pengelolaan keuangan negara, akuntabilitas kinerja, persepsi korupsi, dan pelayanan publik. Permasalahan ketiga adalah jangkauan infrastruktur TIK ke seluruh wilayah dan ke semua lapisan masyarakat yang belum optimal. Infrastruktur TIK khususnya jaringan telekomunikasi merupakan fondasi konektivitas antara penyelenggara SPBE dengan pengguna. Tingkat efektivitas SPBE sangat bergantung pada tingkat aksesibilitas pengguna terhadap Layanan SPBE melalui jaringan telekomunikasi. Berdasarkan data hasil pembangunan infrastruktur TIK dari Kementerian Perencanaan Pembangunan Nasional/Bappenas, 450 kabupaten/kota (87\%) telah terhubung jaringan tulang punggung serat optik nasional, sedangkan 64 kabupaten/kota (13\%) di wilayah tengah dan timur Indonesia belum terhubung. Ditargetkan pada akhir tahun 2019 semua kabupaten/kota di Indonesia akan terhubung jaringan tulang punggung tersebut. Dalam hal pembangunan jaringan pita lebar, teknologi $3 \mathrm{G}$ telah menjangkau 457 kabupaten/kota (89\%), sedangkan jaringan pita lebar dengan teknologi 4G telah menjangkau 412 kabupaten/kota (80\%). Masih terdapat 57 kabupaten/kota (11\%) yang belum terhubung dengan jaringan pita lebar. (Bappenas, 2018) Permasalahan keempat adalah keterbatasan jumlah pegawai ASN yang memiliki kompetensi teknis TIK. Perkembangan TIK menuntut perluasan dan pendalaman kompetensi teknis yang memadai. Pemerintah telah menerbitkan Daftar Unit Kompetensi Okupasi dalam Kerangka Kualifikasi Nasional Indonesia bidang TIK tahun 2019 dengan tujuan menyediakan referensi kompetensi TIK yang dibutuhkan oleh pemerintah, industri TIK, perguruan tinggi, asosiasi profesi bidang TIK, dan lembagalembaga lain yang bergerak di bidang TIK.

Berdasarkan hasil temuan dilapangan ini peneliti menemukan bahwa manajemen Electronic Government di Kota dan Kabupaten Bekasi mengedepankan prinsip good governance didukung kelembagaan yang efektif dan kinerja aparatur yang kompeten, serta pemanfaatan teknologi informasi. Penerapan E- Government di lingkungan pemerintahan dilakukan dalam rangka pemanfaatan teknologi informasi yang akan membawa dampak pada perubahan pola pikir dan cara pandang masyarakat dalam melakukan berbagai kegiatan yang berorientasi pada aspek kemudahan dan kecepatan dalam pertukaran akses informasi. Penerapan EGovernment juga sering dikatakan sebagai salah satu upaya reformasi birorasi menuju terwujudnya good governance. Analisis manajemen Electronic Government dilihat dengan menggunakan empat fungsi manajemen, yakni perencanaan (planning), pengorganisasian (organizing), penggerakan (actuating), dan pengawasan (controlling).

Setiap pemerintah daerah ingin menerapkan tata kelola pemerintahan (good governance) dan memberikan layanan masyarakat (good services) yang baik. Untuk mencapainya, inovasi di bidang teknologi informatika dan telekomunikasi (TIK) jadi satu keharusan. Maka digunakanlah berbagai aplikasi dengan berbagai fungsinya untuk untuk meningkatkan efektivitas dan efisiensi kinerja OPD dan dinas-dinas yang terkait dengan layanan kepada masyarakat. Pemerintah Kota Bekasi melalui wawancara kepada Dr. HR. Dady R. Djajakusumah, S.E, M.si, Kepala Bidang E-Government Diskominfostandi Pemerintah Kota Bekasi. dikatakannya, Pemkot Bekasi telah melakukan banyak upaya dan inovasi untuk menerapkan good governance dan good services melalui "Bekasi Digital Government." Tujuan akhirnya, mempermudah masyarakat untuk memperoleh informasi dan pelayanan di mana saja, kapan sajan dan lewat perangkat apa saja. "Kota Bekasi telah memasuki era digitalisasi dan itu sudah bergerak sejak tahun 2016. Pengembangan sistem digital telah digencarkan sehingga di Kota Bekasi banyak sekali aplikasi, kalau dihitung ada sekitar 80 lebih," Aplikasi untuk efisiensi kerja perangkat daerah hingga aplikasi untuk memberikan layanan masyarakat seperti Aplikasi Pengaduan Masyarakat, Aplikasi Pelaporan Pencegahan Korupsi, Aplikasi Layanan Perizinan, Aplikasi Layanan Kesehatan, Aplikasi Pendidikan dan masih banyak lagi. 
Aplikasi yang ada di setiap OPD dan dinas Pemkot Bekasi maka perlu untuk mengintegrasikanya agar dapat saling terkoneksi. Untuk itu, Diskominfostandi Pemkot Bekasi melakukan terobosan dengan membuat Patriot Decision Support System atau Sistem Pendukung Keputusan dalam bentuk portal. Sederhananya, bagian dan sistem informasi berbasis komputer yang dipakai untuk mengambil keputusan dalam suatu organisai. Berdasarkan hasil wawancara Dr. HR. Dady R. Djajakusumah, S.E, M.si, Kepala Bidang EGovernment Diskominfostandi Pemerintah Kota Bekasi "Kami sendiri yang membuat portal tersebut. Alhamdulillah, sampai dengan saat ini sudah mengintegrasikan 13 perangkat daerah secara aktif dan sudah dapat melakukan pertukaran dan menampilkan data secara real time," Apalagi mengacu pada Rencana Pembangunan Kota Bekasi Tahun 2010 yang memiliki tema "Peningkatan Ketersediaan Prasarana dan Sarana Kota Berbasis Digital Government" maka Patriot Decision Support System dapat membantu dalam meningkat kinerja Pemkot Bekasi dalam pengambilan keputusan. Pada akhirnya, membantu mencapai visi dan misi Kota Bekasi jadi kota digital.

Sedangkan Pemerintah Kabupaten Bekasi, dalam upaya peningkatan dan implementasi Smart City, Pemerintah Kabupaten Bekasi melakukan bentuk Kerjasama dengan Pemkot Bandung terkait Kesepakatan Bersama dan Perjanjian Kerjasama Implementasi Smart City dan E-Government, hal tersebut dijelaskan dalam portal humas Pemda Kabupaten Bekasi “ Rabu 1 November 2017 bertempat di Balaikota Bandung, Wakil Bupati Bekasi Eka Supria Atmaja SH bersama Walikota Bandung M. Ridwan Kamil menandatangani Kesepakatan Bersama dan Perjanjian Kerjasama Implementasi Aplikasi Smart City dan E-Goverment disaksikan oleh Pimpinan KPK Laode M Syarif. Kerjasama antara pemerintah daerah ini mencakup Pemberian Aplikasi Sabilulungan untuk Hibah Bansos, Aplikasi E-Planning untuk Perencanaan, Aplikasi Gampil untuk hal Perijinan serta aplikasi EKinerja dari Pemerintah Kota Bandung kepada 30 Pemerintah Kabupaten/Kota termasuk Kabupaten Bekasi. Dalam kesempatan yang sama, Kadiskominfosantik Drs.Hudaya menyampaikan pernyataannya bahwa beliau sangat mengapresiasi terhadap kegiatan ini dan diharapkan dengan terjalinnya kerjasama antar daerah ini dapat bermanfaat khususnya bagi Pemerintah Kabupaten Bekasi dalam rangka penyelenggaraan pemerintahan yang Good Governance dengan menerapkan EGoverment yang sudah diterapkan lebih dahulu oleh Pemerintah Kota Bandung. Kerjasama ini juga diharapkan dapat meminimalisir terjadinya indak Pidana Korupsi Kolusi dan Nepotisme (KKN) karena dengan sistem berbasis Online dapat meminimalisir pertemuan antara Masyarakat Pemohon dengan
Aparatur Sipil Negara maupun Pejabat yang berwenang khususnya dalam hal Perijinan. Untuk mengatasi permasalahan penerapan SPBE pada penyelenggaraan administrasi pemerintahan, tantangan pemerintah adalah melakukan integrasi layanan perencanaan, layanan penganggaran, layanan pengadaan, dan layanan manajemen kinerja yang berbasis elektronik, baik integrasi internal $\mathrm{K} / \mathrm{L} / \mathrm{D}$ maupun integrasi antar K/L/D secara nasional. Sedangkan untuk mengatasi permasalahan pada pelayanan publik, diperlukan integrasi secara nasional terkait layanan pengaduan publik, layanan perizinan, dan pelayanan publik lainnya yang menjadi tantangan bersama bagi Pemerintah Pusat dan Pemerintah Daerah.

\section{Substansi (Substance)}

Pemerintah menyadari pentingnya peran SPBE untuk mendukung semua sektor pembangunan. Upaya untuk mendorong penerapan SPBE telah dilakukan oleh pemerintah dengan menerbitkan peraturan perundang- undangan sektoral yang mengamanatkan perlunya penyelenggaraan sistem informasi atau SPBE. Terkait dengan otonomi daerah, Undang-Undang Nomor 23 Tahun 2014 tentang Pemerintahan Daerah sebagaimana telah beberapa kali diubah terakhir dengan UndangUndang Nomor 9 Tahun 2015 tentang Perubahan Kedua Undang- Undang Nomor 23 Tahun 2014 tentang Pemerintahan Daerah mengatur kewenangan pemerintah pusat dan pemerintah daerah dalam pengelolaan e-government. Sejauh ini kementerian, lembaga, dan pemerintah daerah telah melaksanakan SPBE secara sendiri-sendiri sesuai dengan kapasitasnya, dan mencapai tingkat kemajuan SPBE yang sangat bervariasi secara nasional.

Untuk membangun sinergi penerapan SPBE yang berkekuatan hukum antara kementerian, lembaga, dan pemerintah daerah, diperlukan Rencana Induk SPBE Nasional yang digunakan sebagai pedoman bagi Instansi Pusat dan Pemerintah Daerah untuk mencapai SPBE yang terpadu. Rencana Induk SPBE Nasional disusun dengan memperhatikan arah kebijakan, strategi, dan inisiatif pada bidang tata kelola SPBE, layanan SPBE, TIK, dan SDM untuk mencapai tujuan strategis SPBE tahun 2018 - 2025 dan tujuan pembangunan aparatur negara sebagaimana ditetapkan dalam RPJP Nasional 2005 2025 dan Grand Design Reformasi Birokrasi 2010 2025.

Pemerintah Kota Bekasi menyikapi terkait penerapan e governance, mengeluarkan Peraturan Wali Kota Bekasi Nomor 08 Tahun 2017 Pedoman Pengelolaan Teknologi Informasi Dan Komunikasi Di Lingkungan Pemerintah Kota Bekasi. Maksud dan tujuan dari peraturan tersebut adalah :

a. Maksud dari pengaturan Pembangunan TIK Perangkat Daerah di Lingkungan Pemerintah Kota Bekasi adalah sebagai pedoman bagi Perangkat Daerah dalam pembangunan Teknologi 
Informasi dan Komunikasi (TIK) di Lingkungan Pemerintah Kota Bekasi.

b. Tujuan pengaturan sebagaimana dimaksud pada ayat (1), adalah:

1) Meningkatkan efisiensi, efektifitas dan akuntabilitas dalam penyelenggaraan pemerintahan, pembangunan dan kemasyarakatan;

2) Melaksanakan interopabilitas Teknologi Informasi dan Komunikasi di Lingkungan Pemerintah Kota Bekasi;

3) Memastikan konsistensi antara Rencana Pembangunan Jangka Menengah Daerah (RPJMD) Kota Bekasi Tahun 2019-2024, Rencana Strategis (Renstra), Masterplan IT Kota Bekasi dan Rencana Aksi Pengembangan Kota Cerdas Kota Bekasi.

\section{Kultur hukum (Legal Culture)}

Faktor kebudayaan sebenarnya bersatu padu dengan faktor masyarakat. Sebagai suatu sistem, maka hukum mencakup, struktur, substansi dan kebudayaan. Penerapan Sistem Pemerintahan Berbasis Elektronik (SPBE) alias "e-government" atau "e-govt" masih mengalami sejumlah kendala dalam penerapan SPBE adalah proses yang belum terintegrasi, ditandai masih rendahnya budaya berbagi data dan informasi antarinstansi pemerintah; infrastruktur teknologi informasi dan komunikasi (TIK) belum menjangkau seluruh instansi, dan pengelolaan keamanan informasi lemah di hampir seluruh instansi pemerintah. (Budi Setiawanto, 2018)

Kehadiran Peraturan Presiden No. 95 Tahun 2018 tentang Sistem Pemerintahan Berbasis Elektronik (SPBE) merupakan babak baru bagi tata kelola atau manajemen pemerintahan di Indonesia. Berdasarkan kebijakan tersebut, seluruh instansi pemerintah wajib menerapkan SPBE atau yang lebih dikenal dengan $e$ - government. Sebenarnya, penggunaan teknologi informasi dan komunikasi (TIK) yang merupakan embrio dari e-government itu sendiri, bukan barang baru di tanah air, termasuk di kalangan birokrasi pemerintah. Namun, dalam implementasinya masih belum optimal, sehingga terjadi inefisiensi. Untuk memetakan e-government secara nasional, tahun 2018, Kementerian Pendayagunaan Aparatur Negara dan Reformasi Birokrasi (PANRB) melakukan evaluasi penerapan $e$ government pada 616 instansi pemerintah. Hasilnya, sebanyak 82 instansi pemerintah $(13,31 \%)$ berpredikat baik, sangat baik, dan memuaskan. Sedangkan, 534 instansi pemerintah $(86,69 \%)$ berpredikat cukup dan kurang. Potret SPBE Nasional itu belum sesuai target yang diharapkan mencapai kategori predikat baik, dengan indeks 2,6 atau lebih yang diharapkan bisa tercapai pada tahun 2020. (Humas MENPANRB, 2019)

Pelaksanaan sistem pemerintahan berbasis elektronik, yang selanjutnya disingkat SPBE di instansi pemerintah pusat dan pemerintah daerah ditujukan untuk mewujudkan proses kerja yang efektif, efisien, transparansi dan akuntabel serta meningkatkan kualitas pelayanan publik. Dalam penerapan penyelenggaraan pemerintahan berbasis elektronik, secara kasat mata telah melahirkan perubahan signifikan dalam lingkungan kerja di birokrasi. Setidaknya terdapat tiga manfaat yang dihasilkan dalam penerapan ini. ${ }^{24}$ Pertama penerapan ini akan meningkatkan efisien dan efektivitas dan kinerja penyelenggaraan pemerintah. Penggunaan perangkat elektronik dipastikan akan mengakses alur birokrasi yang kerapnya rumit dan berbelit. Melalui penggunaan perangkat berbasis elektronik ini, setidaknya akan mengurangi kerumitan tersebut. Kedua, penerapan perangkat berbasis elektronik ini juga akan menghasilkan keunggulan yang strategis (strategic advantage) bagi mareka yang melaksanakan kegiatan. Dampak nyata yang akan muncul diantaranya perubahan dalam struktur organisasi, kondisi manajerial serta rencana pekerjaan. Ketiga, penerapan perangkat berbasis elektronik juga akan mengubah struktur organisasi. Setidaknya penggunaan informasi teknologi, yang mulanya hirarkie organisasi bersifat datar, maka akan sedikit tingkat manajemen yang dibutuhkan. Perkembangan Teknologi akan menciptakan (to create), mengakses (to access), mengelola ( to prosess), dan memanfaatkan (to utilize) informasi secara tepat dan akurat. Informasi merupakan komoditi yang sangat berharga di era globalisasi untuk dikuasai dalam rangka meningkatkan daya saing suatu organisasi secara berkelanjutan.(Zainal A Hasibuan, 2007)

Peraturan Presiden No. 95 Tahun 2018 tentang Sistem Pemerintah Berbasis Elektronik (SPBE) merupakan kebijakan yang bertujuan pemerintah yang efektif, efisien, transparansi dan akuntabel, disamping itu tujuan adanya sistem pemerintah berbasis elektonik supaya infrastruktur teknologi informasi akan dimanfaatkan secara bersama untuk melakukan koordinasi terhadap seluruh instansi, baik pusat maupun daerah. Adapun unsur-unsur Tata Kelola Sistem Pemerintah Berbasis Elektronik (SPBE) secara terpadu, meliputi Rencana Induk SPBE Nasional, Arsitektur SPBE, Peta Rencana SPBE, rencana dan anggaran SPBE, proses bisnis, data dan informasi, infrastruktur SPBE, aplikasi SPBE, keamanan SPBE, serta layanan SPBE. Sistem Pemerintah Berbasis Elektonik pada dasarnya memberikan layanan informasi kepada sesama institusi pemerintahan, kepada dunia bisnis, dan kepada masyarakat dengan tujuan yaitu mampu memberikan informasi lengkap mengenai lembaga 
atau daerah untuk kemajuan ekonomi dan pembangunan daerah, dan peningkatan kinerja proses pelayanan dan mampu mengoptimalkan penggunaan sumber daya seperti tenaga, budget, dan fasilitas lainnya. (Zainal A Hasibuan, 2007)

Dalam penyelenggaraan pemerintah daerah praktik maladministrasi dapat terjadi dari kegiatan pelayanan publik yang diberikan para pejabat publik kepada warga masyarakat. Praktik maladiministrasi cenderung terjadi pada pelayanan publik yang disediakan dengan cara kontak langsung antara penyedia layanan dengan penggunaan jasa layanan. Melalui penerapan sistem pemerintahan berbasis elektonik dapat dicegah terjadinya praktik maladministrasi seperti kolusi dan nepotisme, penyalahgunaan wewenang, permintaan imbalan uang, suap, dan bentuk praktik-praktik maladministrasi lainya. (Erick S. Holle, 2011)

Dengan demikian, kebijakan penerapan sistem pemerintahan berbasis elektronik di Indonesia telah mengalami perkembangan. Kebijakan yang semula diatur dalam bentuk Instruksi Presiden kemudian dirumuskan ke dalam bentuk peraturan perundangundangan yang lebih tinggi sebagai pedoman dan acuan bagi berbagai pihak yang bekerkepentingan termasuk instansi pemerintah dalam menerapkan sistem berbasis elektronik di Indonesia.

\section{Model pencegahan tindak pidana korupsi melalui sistem pemerintah berbasis elektronik.}

Berdasarkan penerapan sistem pemerintah berbasis elektronik, salah satunya untuk memerangi korupsi adalah upaya pencegahan (preventif) disamping upaya penindakan (represif). Bentuk upaya pencegahan adalah dengan sistem elektronik, upaya untuk menutupi kebocoran keuangan negara. Sistem elektronik akan diterapkan memalui jalur online misalnya dalam hal pengadaan barang dan jasa diseluruh instansi pemerintahan, termaksud dalam hal pengawasanya. Sistem pemerintah berbasis elektonik tersebut misalnya e-budgeting, e-purchasing, $e$ catalogue, e-audit, pajak online, IMB online. Berdasarkan fenomena korupsi di pemerintah daerah, banyak faktor yang mempengaruhinya.

a. Monopoli kekuasaan

Adanya kekuatan monopoli pemerintah untuk mengakses sumber daya alam dan sumber daya manusia serta undang-undang. Monopoli pelayanan publik contohnya ketidakadilan perlakukan kepada masyarakat akibat pengambilan keputusan terhadap pelayanan publik, yang menyebabkan ada permintaan dan penawaran dalam pelayanan publik. Untuk meminimalisasi korupsi dan minimnya transparansi tersebut, solusinya dengan pelaksanaan $e$ government disegala bidang dalam sistem pemerintahan.

\section{b. Diskresi kebijakan.}

Diskresi kebijakan adalah kewenangan yang dimiliki pejabat publik dalam membuat kebijakan, hal tersebut dinilai banyak peyalagunaan kewenangan yang berakibat korupsi. Salah satu penerapan $e$ government adalah dengan cara mempersingkat proses perizinan sehingga memperkecil proses birokrasi sehingga transparan.

c. Lemahnya Akuntabilitas.

Pencegahan korupsi dengan adanya peningkatan akuntabilitas seperti partisipasi warga negara dalam proses politik dan pemerintah, birokrasi yang erektif, implementasi peraturan perundangundang.

d. Faktor Lainya

Penyebab kepala daerah korupsi disamping uraian diatas karena biaya pemilukada langsung yang mahal, kurang kompetensi kepala daerah dalam pengelolaan keuangan daerah, tidak pahamnya regulasi peraturan perudang-undangannya, dan serta pemahaman terhadap konsep budaya yang salah. Upaya pembenahan tata kelola pemerintahan dan layanan publik serta pencegahan korupsi sangat bergantung kepada pesatnya perkembangan teknologi. Dalam dunia yang menuju ke digitalisasi di segala aspek ini, masih banyak terdapat bagian dunia yang belum memiliki kemewahan akses terhadap teknologi. Karena itu, akses teknologi untuk pencegahan korupsi akan sangat terbatas pada sumberdaya yang terbatas. Kerangka sistem pemerintahan berbasis elektronik sebagai usaha pemerintah Indonesia untuk menerapkan evidencebased policy makin. Reformasi berbasis digital ini dimulai dari area-area yang berdasarkan pengalaman merupakan daerah beresiko korupsi.

Empat pilar utama dari sistem pemerintahan berbasis elektronik dan upaya reformasi pencegahan korupsi dari pemerintah. Dimulai dari pilar perencanaan dan penganggaran yang saling bisa berkomunikasi dan mendukung money follow program. Kemudian fitur utama dari perbaikan sistem pengadaan barang dan jasa guna mengakselerasi program prioritas pembangunan Indonesia serta fitur dan perluasan e-katalog berbasis sektor dan berbasis daerah. Pilar lanjutannya adalah reformasi system perijinan dengan Online Single Submission (OSS). Dan terakhir digitalisasi sistem peradilan pidana terpadu.

\section{KESIMPULAN}

Berdasarkan pembahasan pada penelitian ini, maka dapat diambil kesimpulan bahwa efektifitas penyelenggaraan otonomi berbasis elektronik belum optimal, masih terdapat permasalahan belum adanya tata kelola SPBE yang terpadu secara nasional, SPBE belum diterapkan pada penyelenggaraan administrasi pemerintahan dan pelayanan publik secara menyeluruh dan optimal, jangkauan infrastruktur TIK ke seluruh wilayah dan ke semua lapisan masyarakat yang belum optimal, keterbatasan jumlah pegawai 
ASN yang memiliki kompetensi teknis TIK. berdasarkan substasi isi peraturan perlu adanya pengaturan kewenangan pemerintah pusat dan pemerintah daerah dalam pengelolaan e-government. Sedangkan kultur masih rendahnya budaya berbagi data dan informasi antarinstansi pemerintah; infrastruktur teknologi informasi dan komunikasi (TIK) belum menjangkau seluruh instansi, dan pengelolaan keamanan informasi lemah di hampir seluruh instansi pemerintah.

Berdasarkan penerapan sistem pemerintah berbasis elektronik terhadap pencegahan tindak pidana korupsi, salah satunya untuk memerangi korupsi adalah upaya pencegahan (preventif) disamping upaya penindakan (represif). Bentuk upaya pencegahan adalah dengan sistem elektronik, upaya untuk menutupi kebocoran keuangan negara. Sistem elektronik akan diterapkan memalui jalur online misalnya dalam hal pengadaan barang dan jasa diseluruh instansi pemerintahan, termaksud dalam hal pengawasanya. Sistem pemerintah berbasis elektonik tersebut misalnya e-budgeting, e-purchasing, ecatalogue, e-audit, pajak online, IMB online.

\section{SARAN}

Hendaknya Instansi Pusat dan Pemerintah Daerah tidak mengedepankan penerapan birokrasi yang kaku dan lambat, tetapi harus menghasilkan birokrasi yang berkinerja tinggi dengan karakteristik integratif, dinamis, transparan, dan inovatif khususnya Pemerintah Daerah Kota dan Kabupaten Bekasi.

Instansi Pusat dan Pemerintah Daerah diharapkan dapat membangun pelayanan publik yang terpadu, efektif, responsif, adaptif, dan mudah diakses oleh masyarakat serta memberikan ruang partisipasi masyarakat dalam turut serta penyusunan kebijakan dan program pembangunan.

Perlu ditingkatkan kompetensi teknis SPBE diharapkan dimiliki oleh pegawai ASN yang terlibat dalam pelaksanaan SPBE antara lain dalam bidang perencanaan SPBE, rekayasa proses bisnis pemerintahan, pengelolaan TIK yang terintegrasi, aman, dan andal, dan pengelolaan layanan yang inovatif, adaptif dan responsif.

\section{REFERENSI}

Achmad Ali. (2001). Keterpurukan Hukum Di Indonesia. Jakarta: Ghalia Indonesia.

Bappenas. (2018). Hasil Pembangunan Infrastruktur TIK. Retrieved from Kementerian Perencanaan Pembangunan Nasional website: https://www.bappenas.go.id/id/

Budi Setiawanto. (2018). Ini Kendala Penerapan Sistem Pemerintahan Berbasis Elektronik Menurut Kementerian PANRB.

Dien Novita. (2014). Faktor-Faktor Penghambat Pengembangan E-Government: Studi Kasus Pemerintah Kota Palembang, Sumatera
Selatan. EKSPLORA INFORMATIKA, 4(1), 43-52.

Dirjen Aptika Kemkominfo. (2019). Tabel Hasil Pemeringkatan E-Government Indonesia. Retrieved from Aptika Kemkominfo website: https://aptika.kominfo.go.id

Erick S. Holle. (2011). PELAYANAN PUBLIK MELALUI ELECTRONIC GOVERNMENT: UPAYA MEMINIMALISIR PRAKTEK MALADMINISTRASI DALAM MENINGKATAN PUBLIC SERVICE. Jurnal Sasi, 17(3), 21-30. https://doi.org/https://doi.org/10.47268/sasi.v1 $7 \mathrm{i} 3.362$

Firdaus, A. (2018). Transformasi Smart City Kota Bekasi.

Humas MENPANRB. (2019). Babak Baru Sistem Pemerintahan Berbasis Elektronik. Retrieved from www.menpan.go.id website: https://www.menpan.go.id/site/beritaterkini/babak-baru-sistem-pemerintahanberbasis-elektronik

Iqbal Aidar Idrus, Ummi Zakiyah, and L. H. (2017). Kajian Sukses Implementasi E-Goverment Studi Kasus Pemerintah Kota Bogor. JURNAL OF GOVERNMENT - JOG (Kajian Manajemen Pemerintahan \& Otonomi Daerah), 2(2), 120-134.

Lia Hutasoit. (2018). KPK Sudah Tangkap 100 Kepala Daerah, Ini Daftar Lengkapnya. Retrieved from IDN Times website: https://www.idntimes.com/news/indonesia/liahutasoit/daftar-lengkap-100-kepala-daerahditangkap-kpk-sejak/full

Loura Hardjaloka. (2015). Penerapan e-government di Indonesia dan negara lainnya sebagai solusi pemberantarasan korupsi di sector publik. Jurnal Rechts Vinding, 3(3), 435-452.

Maryuni, S. (2015). Implementation of The National Community Empowerment Program (PNPM) In Pontianak. Spirit Publik, 10(1), 19-30.

Medan Yonathan Mael. (2017). Implementasi Kebijakan Pemerintah dalam Meningkatkan Kesejahteraan Petani melalui Program Padat Karya Pangan di Kecamatan Noemuti. Agrimor Jurnal AgribisnisLahan Kering, 2(4), 48-49.

Meijer, A., \& Bolívar, M. P. R. (2016). Governing the smart city: a review of the literature on smart urban governance. International Review of Administrative Sciences. International Review of Administrative Sciences, 82(2), 392-408.

Mukti fajar dan Yulianto Achmad. (2013). Dualisme Penelitian Hukum Normatif Dan Empiris. Yogjakarta: Pustaka Pelajar.

Ni'matul Huda. (2005). Hukum Tata Negara Indonesia. Jakarta: Raja Grafindo Persada.

Rianto Budi, T. L. (2012). Polri \& Aplikasi EGovernment dalam Pelayanan Publik. Surabaya: CV. Putra Media Nusantara (PMN). 
Richardus Eko Indrajit. (2002). Elektronic Government Strategi Pembangunan Dan Pengembangan Sistem Pelayanan Publik Berbasis Teknologi Digital. Yogjakarta: Andi.

Ronny Hanitijo Soemitro Dalam bukunya Mukti Fajar dan Yulianto Achmad. (2010). Dualisme Penelitian Hukum (Normative Dan Empiris). Yogjakarta: Pustaka Pelajar.

Sandhu, S. (2009). Strategic Communication: An Institutional Perspective. International Journal of Strategic Communication, 3(2), 72-92. https://doi.org/https://doi. org/10.1080/15531180902805429

Soerjono Soekanto. (1985). Efektifitas Hukum Dan Penerapan Sanksi. Bandung: Remadja Karya.

Yud. (2019). Program Smart City Kota Bekasi Dinilai Hanya Sebatas Wacana. Retrieved from Radarnonstop.co website: https://m.radarnonstop.co

Zainal A Hasibuan. (2007). Langkah-Langkah Stategis dan Taktis Pengembangan EGovernment Untuk Pemda. Sistem Informasi MTI UI, 3(1), 1.

\section{PROFIL PENULIS}

Dr. (c) Rahmat Saputra, SH.,MH juga merupakan Dosen Tetap Program Studi Ilmu Hukum Fakultas Hukum Universitas Bhayangkara Jakarta Raya.

Dr. Apriyanti Widiasnyah, SS.,MPd merupakan Dosen Tetap Program Studi Ilmu Pendidikan, Universitas Bhayangkara Jakarta Raya. 